\title{
Electrodessication and Curettage
}

National Cancer Institute

\section{Source}

National Cancer Institute. Electrodessication and Curettage. NCI Thesaurus. Code C116567.

A procedure that uses both a curette and hyfrecator for treatment of various skin conditions, including basal cell carcinoma, squamous cell skin carcinoma, viral warts, and pyogenic granulomas. 